\title{
Article \\ Prevalence of Anisakis Larvae in Different Fish Species in Southern Albania: Five-Year Monitoring (2016-2020)
}

\author{
Enkeleda Ozuni ${ }^{1}$, Ani Vodica ${ }^{2}$, Marta Castrica $\left.{ }^{3, *} \mathbb{(}\right)$, Gabriele Brecchia ${ }^{4}$, Giulio Curone ${ }^{4} \oplus$, Stella Agradi ${ }^{4}$,

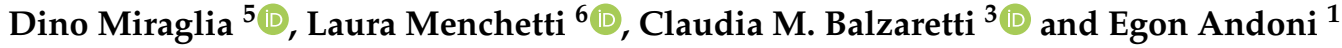

1 Veterinary Faculty of Tirana, Department of Public Health, Agricultural University of Tirana. Rr "Pajsi Vodica", Koder-Kamez, 1029 Tirana, Albania; enkeleda.ozuni@ubt.edu.al (E.O.); eandoni@ubt.edu.al (E.A.)

2 Food Safety and Veterinary Institute, Rr "Aleksander Moisiu" No 82, 1005 Tirana, Albania; ani.vodica@isuv.gov.al

3 Department of Health, Animal Science and Food Safety "Carlo Cantoni", University of Milan, Via Dell' Università 6, 26900 Lodi, Italy; claudia.balzaretti@unimi.it

4 Department of Veterinary Medicine, University of Milan, Via dell'Università 6, 26900 Lodi, Italy; gabriele.brecchia@unimi.it (G.B.); giulio.curone@unimi.it (G.C.); stella.agradi@unimi.it (S.A.)

5 Department of Veterinary Medicine, University of Perugia, Via San Costanzo 4, 06126 Perugia, Italy; dino.miraglia@unipg.it

6 Department of Agricultural and Food Sciences, Alma Mater Studiorum University of Bologna, Viale Fanin 46, 40127 Bologna, Italy; laura.menchetti@unibo.it

* Correspondence: marta.castrica@unimi.it

Citation: Ozuni, E.; Vodica, A.; Castrica, M.; Brecchia, G.; Curone, G.; Agradi, S.; Miraglia, D.; Menchetti, L.; Balzaretti, C.M.; Andoni, E. Prevalence of Anisakis Larvae in Different Fish Species in Southern Albania: Five-Year Monitoring (2016-2020). Appl. Sci. 2021, 11, 11528. https://doi.org/10.3390/ app112311528

Academic Editor: Catarina Guerreiro Pereira

Received: 6 November 2021

Accepted: 2 December 2021

Published: 5 December 2021

Publisher's Note: MDPI stays neutral with regard to jurisdictional claims in published maps and institutional affiliations.

Copyright: (c) 2021 by the authors. Licensee MDPI, Basel, Switzerland. This article is an open access article distributed under the terms and conditions of the Creative Commons Attribution (CC BY) license (https:// creativecommons.org/licenses/by/ $4.0 /)$.
Abstract: Anisakidae are nematodes that commonly parasitize in the coelomic cavity and viscera of several fish species. They can be found in flesh, which is why they have an important economic and public health impact. The aim of the current work was to assess the presence and prevalence of Anisakis larvae in fish species caught in the coastal area of the Karaburun Peninsula in Vlora Bay (Albania). A total of 856 of wild teleosts and 219 specimens of farmed fish were collected over a 5 -year period (from 2016 to 2020). The results showed that out of a total of 1075 analyzed samples, $361(33.58 \%)$ were parasitized with L3 larvae. In particular, only Solea vulgaris returned negative results, while Sparus aurata, Dicentrarchus labrax, and Sardinella aurita showed the lowest prevalence $(4.55 \%, 9.17 \%$, and $10.53 \%$, respectively) and mean abundance $(0.84,1.19$, and 0.92 , respectively). Conversely, Scomber japonicus and Scomber scombrus showed the highest prevalence $(74.07 \%$ and $68.00 \%$, respectively) and mean abundance (188.24 and 249.82, respectively). The data suggest that the coastal area of the Karaburun Peninsula (southern Albania) may be a high-risk area for zoonotic diseases, and the consumption of raw or undercooked fish caught in the Vlora district could result in the acquisition of human anisakiasis. For these reasons, it is necessary to improve the surveillance plan.

Keywords: anisakiasis; Anisakis infection; zoonotic diseases; infection risk factors

\section{Introduction}

Fish provide excellent nutritious value, being rich in essential polyunsaturated fatty acids (PUFAs), especially omega-3 and omega-6, vitamins, and minerals [1]. For this reason, the demand for high-quality fish and fishery products has always shown a positive trend. Furthermore, in 2018, the world fish and aquaculture production reached about 179 million tons [2]. In this context, its safety aspects, such as the potential transmission of zoonotic diseases, play a crucial role in human health. In 2012, the World Health Organization (WHO) estimated that there were approximately 56 million cases of parasite infections due to the consumption of fish products [3].

From the European Union Rapid Alert System for Food and Feed (RASFF) database, when only taking into account the parasitic infections by Anisakis, 546 notifications were found in the EU. The latter extended from 2001 to 2019 in 13 different European Union 
countries, reflecting $0.95 \%$ of the total cases reported on the RASFF portal. The peak of the notifications occurred in the year 2011, representing $19 \%$ of the number of total notifications of Anisakis [4]. Of the 546 Anisakis notifications, the main notified taxa were mackerel (123 notifications) and hake (106 notifications), followed by anglerfish (94 notifications) and anchovy (29 notifications) [4].

Among several types of fish parasites, the genus Anisakis deputes the widely distributed fish nematodes, capable of inducing ichthyozoonosis disease. A recent systematic literature survey carried out by Ophranet [5] estimated that the worldwide incidence of zoonotic cases attributed to Anisakis species in 2021 is to $0.32 / 100,000$. Anisakis are parasitic nematodes belonging to the phylum Nemathelmintes, class Secernentea, order Ascarida, suborder Ascaridina, superfamily Ascaridoidea, family Anisakidae and subfamily Anisakinae [6]. The genus Anisakis comprises nine species; however, only two of them, A. simplex s.s. and $A$. pegreffii, have been confirmed as zoonotic pathogens [7,8], while Pseudoterranova decipiens and Contracaecum osculatum always belonging to the anisakid genera rarely were considered responsible for infections in humans [9].

Intermediate or paratenic hosts of the larvae are crustaceans, cephalopods, and fish [10]. Anisakis larvae can be found parasitizing a wide range of marine teleost species inhabiting the Atlantic and the Mediterranean, as well as from the Pacific to the Antarctic area, affecting the fish product quality [11]. Anisakidosis is the zoonotic disease caused by the third larval (L3) stage of anisakid nematodes [12]. Anisakiasis is a worldwide emerging zoonosis which also causes serious economic problems related to the marketability of infested fishery products and the potential negative effects on consumer confidence [13-15]. Humans, who are not suitable hosts for these parasites, acquire the infection accidentally by eating mainly raw, salted and marinated, or undercooked fish or cephalopods [16]. Using raw or almost raw fish products exposes consumers to a significant health risk [17].

Therefore, thermal processing (heat treatment) is the most reliable way to check the risk of infection through consuming raw or undercooked infected fish, specifically through the application of temperatures $\geq 60{ }^{\circ} \mathrm{C}$ for 1 minute, $60^{\circ} \mathrm{C}$ for $10 \mathrm{~min}$, or $70{ }^{\circ} \mathrm{C}$ for $7 \mathrm{~min}$ (for a fillet $3 \mathrm{~cm}$ thick) [4,18]. Moreover, European Regulation No. 1276/2011 urges food business operators to employ a mandatory application of preventive freezing treatment on raw materials or finished products in order to kill viable parasites in fishery products. The freezing treatment, for parasites other than trematodes, must consist of lowering the temperature in all parts of the product to at least $-20^{\circ} \mathrm{C}$ for at least $24 \mathrm{~h}$ or $-35^{\circ} \mathrm{C}$ for at least $15 \mathrm{~h}$.

In order to invade the gastrointestinal mucosa, the L3 of A. simplex probably use mechanical disruption of tissue combined with the release of potent proteolytic enzymes that are capable of degrading the extracellular matrix [14]. The clinical manifestations differ depending on the larva location, where the most habitual location is in the mucosa or submucosa of the stomach and intestine [19]. There are four specific forms of infection recognized today, depending on the site of larval penetration and the accompanying pathology: gastric, intestinal, ectopic, and gastro-allergic [20]. Human anisakidosis is peculiar because this parasite is not adapted to live in humans, and for this reason, the infection is defined as "transitory". In fact, the chronological physiopathology of Anisakis simplex infection in humans shows that about 14 days after ingestion, larval death occurs [14]. Usually within a few hours after the ingestion of a living worm, $A$. simplex causes an infection that may lead to abdominal pain, nausea, vomiting, or diarrhea [14], whereas allergic-type reactions emerge within 60-120 min after the consumption of affected fish [18]. Diagnosing anisakiasis is a difficult task, and an accurate identification relies on the endoscopy or determination of specific IgE against $A$. simplex, in addition to the fact that anisakiasis symptoms are non-specific and the disease often being misdiagnosed [18].

The region of Vlora is the most important city in Albania, with significant tourist and economic potential [21] and with the combination of globalization and food tourism. In recent years, there has been an increase in cuisine in Albania based on the consumption of raw fish dishes or Japanese sushi. However, many restaurants are often unaware 
of the freezing techniques required to preserve fish and frequently use raw fillets from fresh fish that serve as a pathway for the spread of Anisakis disorders. Safety measures for consumer protection are increasing in Albania, and since 2014, national surveillance programs have included Anisakis control for fish species. Public health authorities and veterinary services are aware of the problem and are implementing a monitoring plan for Anisakis as a necessary operation for traceability. At the same, the fish industry is aware of the problem, which can affect both human health and the commercial value of the product.

In this context, the purpose of this research was to evaluate the prevalence of Anisakidae larvae in 10 fish species in the coastal region of Vlora (southern Albania). To date, this is the first study regarding Anisakis risk infection factors conducted in Albania and over such an extensive and large sampling period. In particular, this study evaluated the epidemiological situation over 5 years (2016-2020). The results could provide a significant contribution to Anisakis risk analysis in Albania while defining a more precise risk assessment and communication for consumers.

\section{Materials and Methods}

\subsection{Sampling}

A total of 1075 fish specimens of 10 different teleost species were collected from different sites on the coast of the Karaburun Peninsula located in the Valona district during 2016-2020 (Figure 1). Two of the fish specimens (Dicentrarchus labrax and Sparus aurata) were farmed fish and were reared in floating cages. Eight species (Merluccius merluccius, Solea vulgaris, Scomber scombrus, Mullus barbatus, Engraulis encrasicolus, Sardinella aurita, Trachurus trachurus, and Scomber japonicus) were collected with gillnets in the surrounding waters.

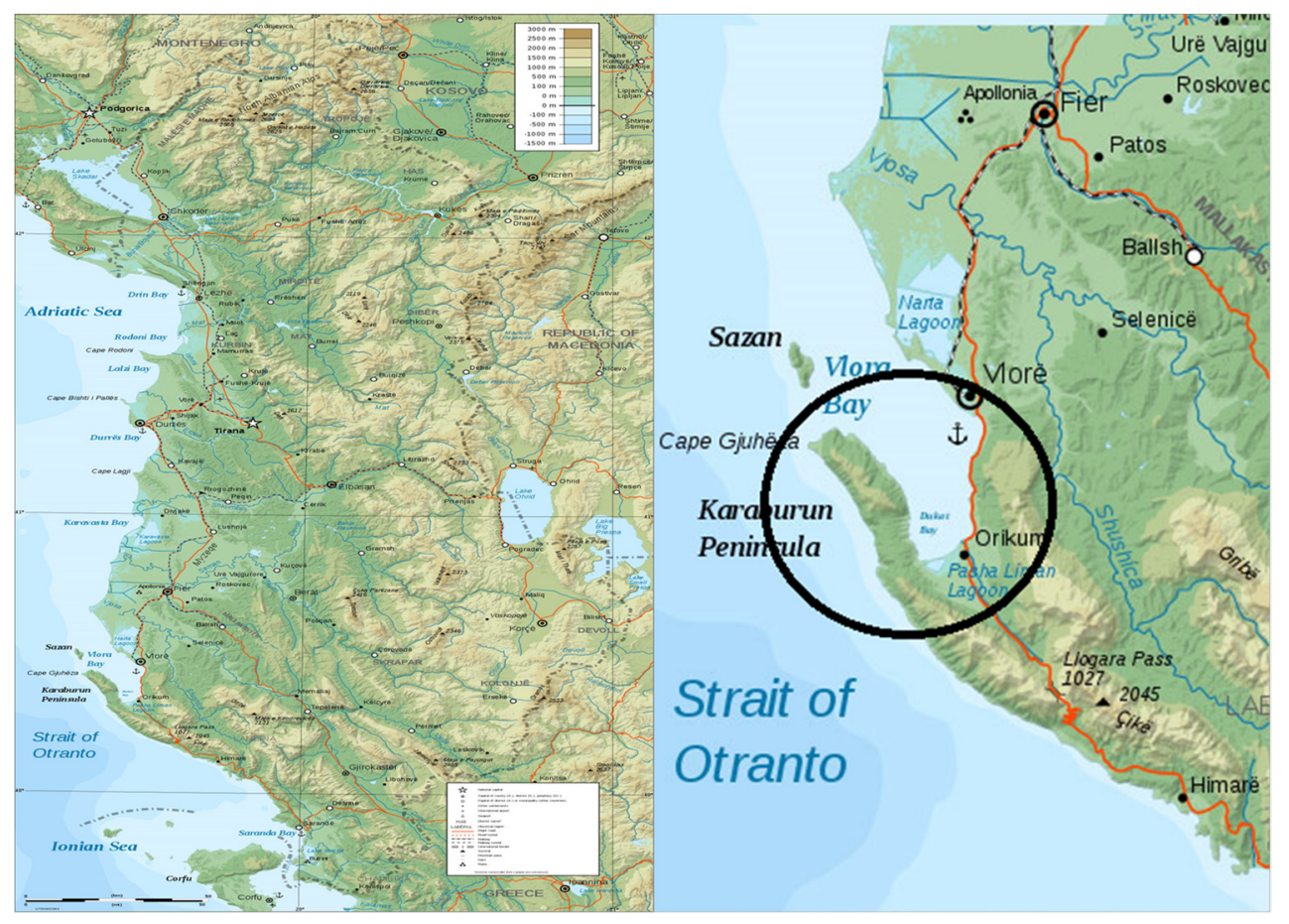

Figure 1. Fishing sampling zone: Vlore, Karaburun (40.35417272574143, 19.438298354632305).

\subsection{Fish Inspection}

All the specimens were selected randomly and were part of a national monitoring program to evaluate anisakidosis risk assessment in the Albanian population. The fish were transported instantly into the laboratory and were kept at $4{ }^{\circ} \mathrm{C}$ until arrival in the laboratory. All of the detected larvae were collected with their locations noted and then washed in saline solution and subjected to morphological identification at the genus level according 
to the morphological keys of Moravec (1994) [22]. The viscera were dissected under a stereoscopic microscope, and the flesh, after a previous visual inspection, underwent artificial enzymatic digestion [23]. Furthermore, the coelomic cavity was opened, and the information regarding the number of larvae for each fish was recorded.

\subsection{Morphological Identification of Anasikid L3}

The samples were delivered to the laboratory of the veterinary faculty of Tirana in coolers $\left(4^{\circ} \mathrm{C}\right)$ within approximately $6 \mathrm{~h}$ after fishing. Upon arrival in the laboratory, the fish were visually examined (Figure $2 a, b$ ), and the flesh underwent the digestion method according the procedure of the EURL for parasites [24]. After the fish were skinned and eviscerated, the muscular tissue was collected and weighed (XS Balance Mod. BL 224220 GR.-0.1 MG) to the amount of $100 \mathrm{~g}$ of muscle. The muscles were chopped and transferred in the digestion solution (2 L tap water preheated to $46-48^{\circ} \mathrm{C} ; 10 \pm 0.5 \mathrm{~mL}, 25 \%$ hydrochloric acid (37\% ERBApharm, according to the pharmacopoeia: Ph.Eur.-NF-FUPh Franc.-BP-JPand); $10 \pm 0.2$ g pepsin (Pepsine 1:10,000 Biotechnology Grade VWR)). The beaker was placed on a magnetic stirrer (ELP Scientific F20510011) with the heating plate at $40-42{ }^{\circ} \mathrm{C}$. The solution was incubated under stirring conditions until the tissue disappeared (approximately 15-20 min), with the glass beaker covered by aluminum foil to keep a constant temperature and decrease evaporation. Then, the digestion solution was poured through the sieve into a beaker. The Anisakis larvae could be detected on the sieve, collected, and examined under a stereomicroscope (0.67 X-4.5 X Zoom stereo microscopes, Model VS6745-J4L). All the larvae were stored in the laboratory in vial filled with $90 \%$ ethanol.

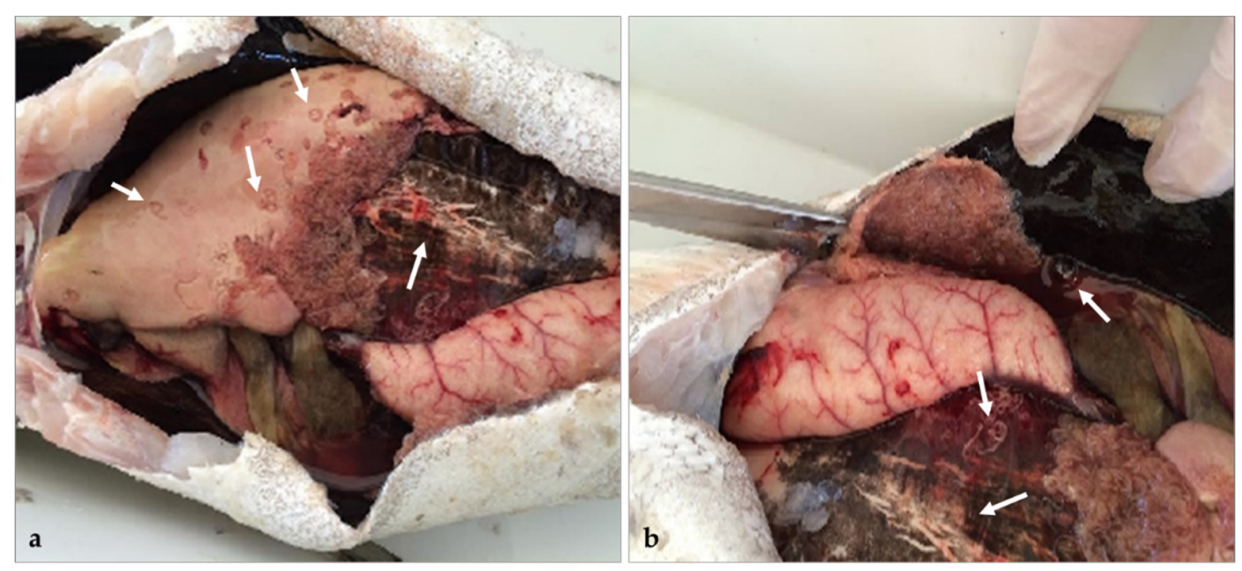

Figure 2. (a,b) Merluccius merluccius heavily infected with Anisakis larvae. The larvae were found in the liver and visceral organs (arrows).

\subsection{Data Analysis}

The standard infection parameters suggested by Bush et al. [25] were used to quantify the parasite population and parasite infection density in the host population. In particular, "prevalence" was calculated as the number of hosts infected with 1 or more individuals of Anisakis divided by the number of hosts examined for that parasite species; "intensity" was calculated as the number of larvae of Anisakis in a single infected host; "mean intensity" was calculated as the total number of parasitic larvae of Anisakis found in a sample divided by the number of hosts infected with them; and "mean abundance" was calculated as the total number of larvae of Anisakis in a sample of a particular host species divided by the total number of hosts of that species examined (including both infected and uninfected hosts). The confidence interval (95\% CI) for the mean abundance was calculated using the bootstrap method [26,27]. These parameters were also calculated for each site of parasitation (viscera and flesh) and season. Generalized linear models using a binomial as the probability distribution and a logit as the link function were used to evaluate whether the Anisakis infection was affected by the fish species, site of parasitation, or season. The 
least significant difference was used to carry out pairwise comparisons. Moreover, the abundance was compared between the sites of parasitation through the Wilcoxon signedrank test, while the abundance was compared between the fish species and seasons using the Kruskal-Wallis test [27]. Statistical analyses were performed with SPSS Statistics version 25 (IBM, SPSS Inc., Chicago, IL, USA). We defined $p \leq 0.05$ as significant.

\section{Results}

Table 1 and Figures 3 and 4, regardless of the parasite microhabitat (viscera or flesh) and season of capture, show the prevalence, mean abundance, and intensity of infection of anisakid L3 type I larvae in 10 fish species. A total of 361 (33.58\%) specimens were parasitized. Out of the 10 different fish species exanimated in this research, 9 of them showed contamination with Anisakis larvae. Only one fish species, Solea vulgaris, returned a negative result (Table 1). Sparus aurata showed the lowest prevalence and mean abundance, followed by Dicentrarchus labrax and Sardinella aurita (Figures 3 and 4). Conversely, the highest prevalence and mean abundance were recorded in Scomber japonicus and Scomber scombrus, respectively (Figures 3 and 4), which also exhibited high intensities $(20,330$ and 24,982, respectively; Table 1).

Table 1. Prevalence (\%), mean abundance, $95 \%$ confidence intervals (calculated using the bootstrap method), mean, intensity range (minimum-maximum), and total number of larvae.

\begin{tabular}{|c|c|c|c|c|c|c|c|}
\hline Fish Species & No. & Prevalence & $\begin{array}{c}\text { Mean } \\
\text { Abundance }\end{array}$ & $\begin{array}{l}95 \% \text { CI for Mean } \\
\text { Abundance }\end{array}$ & Mean Intensity & Range & $\begin{array}{c}\text { Total Number } \\
\text { of Larvae }\end{array}$ \\
\hline Dicentrarchus labrax & 109 & $9.17 \%$ & 1.19 & $0.38-2.01$ & 13.00 & $1-23$ & 130 \\
\hline Engraulis encrasicolus & 112 & $50.00 \%$ & 73.42 & 58.39-88.44 & 146.84 & $72-255$ & 8223 \\
\hline Merluccius merluccius & 112 & $26.79 \%$ & 4.57 & $2.93-6.21$ & 17.07 & 5-35 & 512 \\
\hline Mullus barbatus & 100 & $25.00 \%$ & 4.78 & $2.84-6.72$ & 19.12 & $2-41$ & 478 \\
\hline Sardinella aurita & 114 & $10.53 \%$ & 0.92 & $0.38-1.46$ & 8.75 & $3-15$ & 105 \\
\hline Scomber japonicus & 108 & $74.07 \%$ & 188.24 & $156.53-219.95$ & 254.12 & $32-635$ & 20,330 \\
\hline Scomber scombrus & 100 & $68.00 \%$ & 249.82 & 202.13-297.51 & 367.38 & $34-792$ & 24,982 \\
\hline Solea vulgaris & 100 & $0.00 \%$ & 0.00 & $0.00-0.00$ & - & - & - \\
\hline Sparus aurata & 110 & $4.55 \%$ & 0.84 & $0.08-1.59$ & 18.40 & $10-24$ & 92 \\
\hline Trachurus trachurus & 110 & $68.18 \%$ & 135.51 & $107.89-163.12$ & 198.75 & $30-639$ & 14,906 \\
\hline
\end{tabular}

Quantitative descriptors of the parasite populations according to the microhabitat of parasitation are presented in Table 2. Both in the viscera and flesh, Sparus aurata was the fish infested with Anisakis the least, while Scomber japonicus was the heaviest. Overall, both the prevalence and mean abundance were higher in the viscera (prevalence $=33.58 \pm 1.4 \%$; abundance $=61.15 \pm 130.31$ helminths $/$ host ) than the flesh (prevalence $=27.91 \pm 1.4 \%$; abundance $=3.74 \pm 10.39$ helminths $/$ host; $p<0.001$ ).

Regardless of the fish species, the season of capture affected the susceptibility to infection. The highest prevalence and mean abundance were recorded in the summer and spring, with the lowest being in the winter $(p<0.05$; Tables 3 and 4$)$. In particular, the differences in prevalence were statistically significant in Sardinella aurita, where one season (winter) returned a negative result $(p<0.05$; Table 3). Differences in the mean abundance were found in several species; Engraulis encrasicolus, Scomber japonicus, and Scomber scombrus had about half the number of larvae in winter than in summer and spring $(p<0.05 ;$ Table 4$)$. 


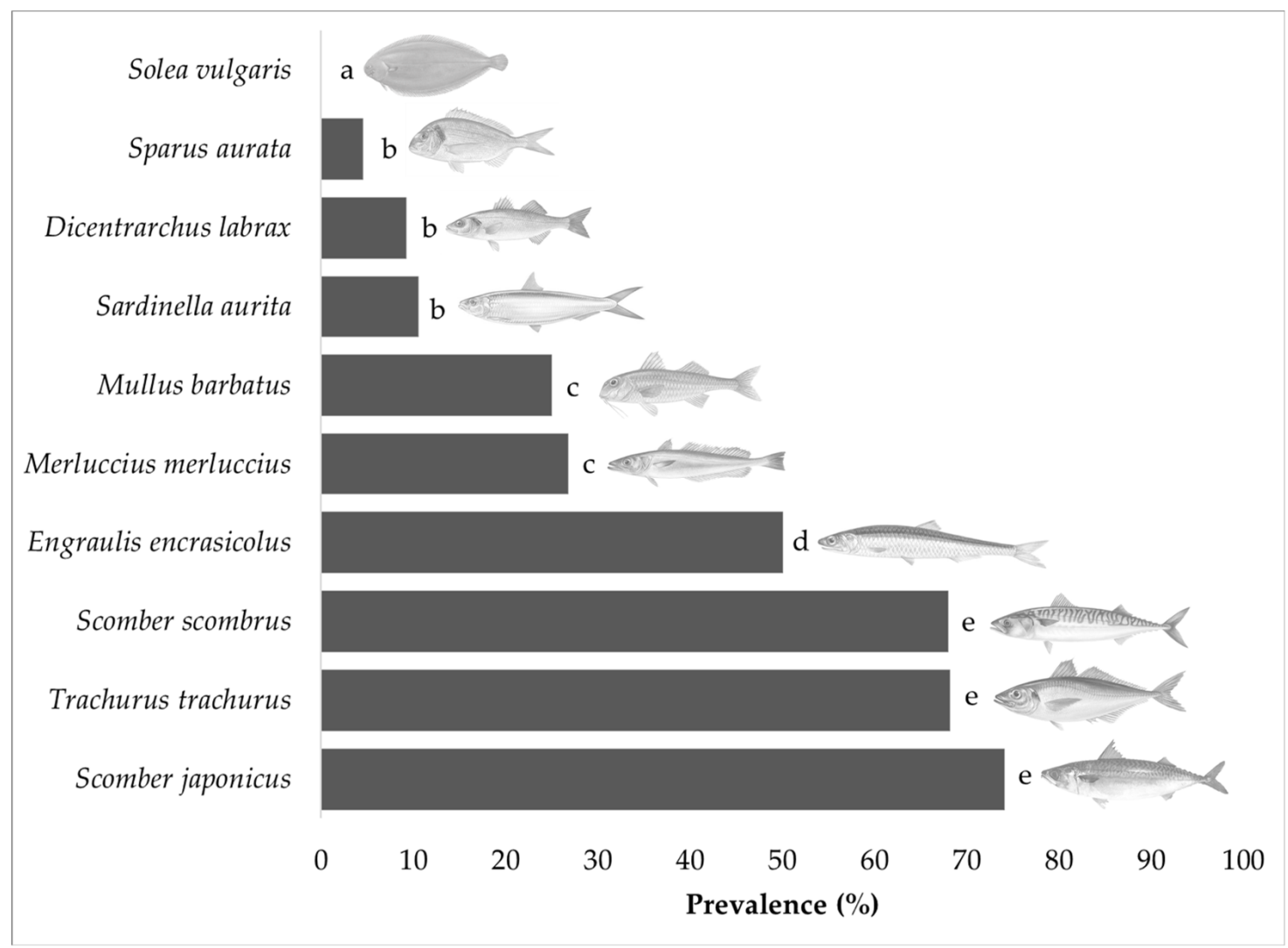

Figure 3. Prevalence (\%) of anisakid L3 type I larvae in the fish species. Bars sharing the same letters are not significantly different $(p<0.05)$.

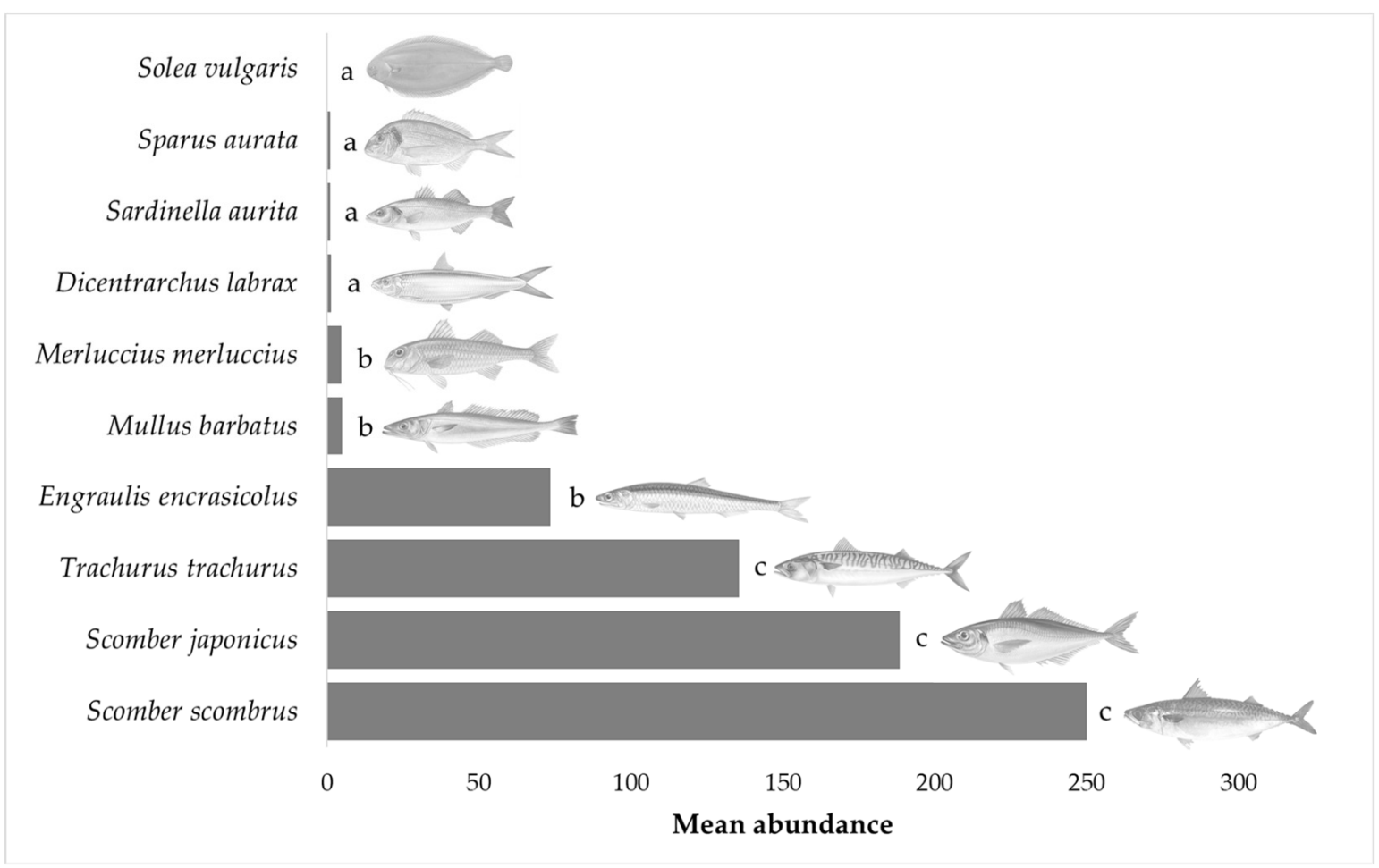

Figure 4. Mean abundance (helminths/host) of anisakid L3 type I larvae observed in the fish species. Bars sharing the same letters are not significantly different $(p<0.05)$. 
Table 2. Prevalence (\%) and mean abundance with 95\% confidence intervals (calculated using the bootstrap method) of anisakid L3 type I larvae in the fish species, analyzed with respect to the microhabitat of parasitation.

\begin{tabular}{lcccc}
\hline \multirow{2}{*}{ Fish Species } & \multicolumn{2}{c}{ Prevalence } & \multicolumn{2}{c}{ Mean Abundance with 95\% CI } \\
\cline { 2 - 5 } & Viscera & Flesh & Viscera & Flesh \\
\hline Dicentrarchus labrax & $9.17 \%$ & $7.34 \%$ & $1.01(0.33-1.69)$ & $0.18(0.03-0.34)$ \\
Engraulis encrasicolus & $50.00 \%$ & $45.54 \%$ & $59.79(47.21-72.36)$ & $13.63(9.20-18.06)$ \\
Merluccius merluccius & $26.79 \%$ & $18.75 \%$ & $4.02(2.59-5.45)$ & $0.55(0.31-0.80)$ \\
Mullus barbatus & $25.00 \%$ & $19.00 \%$ & $3.76(2.29-5.23)$ & $1.02(0.49-1.55)$ \\
Sardinella aurita & $10.53 \%$ & $0.00 \%$ & $0.92(0.38-1.46)$ & 0.00 \\
Scomber japonicus & $74.07 \%$ & $65.74 \%$ & $179.78(149.63-209.92)$ & $8.46(6.71-10.21)$ \\
Scomber scombrus & $68.00 \%$ & $61.00 \%$ & $242.16(195.91-288.41)$ & $7.66(5.77-9.55)$ \\
Solea vulgaris & $0.00 \%$ & $0.00 \%$ & 0.00 & 0.00 \\
Spara aurata & $4.55 \%$ & $3.64 \%$ & $0.66(0.08-1.25)$ & $0.17(0.00-0.35)$ \\
Trachurus trachurus & $68.18 \%$ & $59.09 \%$ & $129.97(103.90-156.05)$ & $5.54(3.56-7.51)$ \\
\hline
\end{tabular}

Table 3. Prevalence (\%) of anisakid L3 type I larvae in the fish species, analyzed with respect to the season of capture. Values followed by the same letters are not significantly different.

\begin{tabular}{|c|c|c|c|c|c|}
\hline \multirow[b]{2}{*}{ Fish Species } & \multicolumn{4}{|c|}{ Season of Capture } & \multirow[b]{2}{*}{$p$ Value } \\
\hline & $\begin{array}{c}\text { Spring } \\
(n=268)\end{array}$ & $\begin{array}{l}\text { Summer } \\
(n=278)\end{array}$ & $\begin{array}{l}\text { Autumn } \\
(n=267)\end{array}$ & $\begin{array}{l}\text { Winter } \\
(n=262)\end{array}$ & \\
\hline Dicentrarchus labrax & 11.11 & 14.29 & 7.41 & 3.70 & 0.477 \\
\hline Engraulis encrasicolus & 57.14 & 53.33 & 46.43 & 42.31 & 0.684 \\
\hline Merluccius merluccius & 28.57 & 32.14 & 25.00 & 21.43 & 0.819 \\
\hline Mullus barbatus & 24.00 & 32.00 & 24.00 & 20.00 & 0.809 \\
\hline Sardinella aurita & $14.29 \mathrm{a}$ & $13.79 \mathrm{a}$ & $13.79 \mathrm{a}$ & $0.00_{b}$ & 0.003 \\
\hline Scomber japonicus & $77.78^{\circ}$ & 85.19 & 70.37 & 62.96 & 0.237 \\
\hline Scomber scombrus & 69.2 & 70.00 & 66.67 & 65.22 & 0.982 \\
\hline Solea vulgaris & 0.00 & 0.00 & 0.0 & 0.00 & - \\
\hline Spara aurata & 7.41 & 7.14 & 3.57 & 0.00 & 0.148 \\
\hline Trachurus trachurus & 74.07 & 72.41 & 62.96 & 62.96 & 0.713 \\
\hline Overall & $36.6 \mathrm{a}$ & $38.8 \mathrm{a}$ & $31.1_{\mathrm{ab}}$ & $27.5_{b}$ & 0.019 \\
\hline
\end{tabular}

Table 4. Mean abundance with 95\% confidence intervals (calculated using the bootstrap method) of anisakid L3 type I larvae in the fish species, analyzed with respect to the season of capture. Values followed by the same letters are not significantly different.

\begin{tabular}{|c|c|c|c|c|c|}
\hline \multirow[b]{2}{*}{ Fish Species } & \multicolumn{4}{|c|}{ Season of Capture } & \multirow[b]{2}{*}{$p$ Value } \\
\hline & $\begin{array}{l}\text { Spring } \\
(n=268)\end{array}$ & $\begin{array}{l}\text { Summer } \\
(n=278)\end{array}$ & $\begin{array}{l}\text { Autumn } \\
(n=267)\end{array}$ & $\begin{array}{c}\text { Winter } \\
(n=262)\end{array}$ & \\
\hline Dicentrarchus labrax & $\begin{array}{c}1.81 \\
(0.00-3.89)\end{array}$ & $\begin{array}{c}2.50 \\
(0.00-5.00)\end{array}$ & $\begin{array}{c}0.37 \\
(0.00-0.90)\end{array}$ & $\begin{array}{c}0.04 \\
(0.00-0.11)\end{array}$ & 0.491 \\
\hline Engraulis encrasicolus & $\begin{array}{c}95.36 \mathrm{a} \\
(61.38-129.33)\end{array}$ & $\begin{array}{c}94.43 \mathrm{a} \\
(59.04-129.82)\end{array}$ & $\begin{array}{c}55.96 \mathrm{ab} \\
(31.18-80.75)\end{array}$ & $\begin{array}{c}44.35_{b} \\
(21.60-67.09)\end{array}$ & 0.030 \\
\hline Merluccius merluccius & $\begin{array}{c}6.46 \\
(2.25-10.68) \\
\end{array}$ & $\begin{array}{c}6.29 \\
(2.42-10.15)\end{array}$ & $\begin{array}{c}3.86 \\
(0.62-7.10)\end{array}$ & $\begin{array}{c}1.68 \\
(0.37-2.89)\end{array}$ & 0.504 \\
\hline Mullus Barbatus & $\begin{array}{c}5.52 \\
(1.27-9.77) \\
\end{array}$ & $\begin{array}{c}9.12 \\
(3.28-14.96) \\
\end{array}$ & $\begin{array}{c}3.48 \\
(0.66-6.30) \\
\end{array}$ & $\begin{array}{c}1.00 \\
(0.08-1.92) \\
\end{array}$ & 0.430 \\
\hline Sardinella aurita & $\begin{array}{c}1.00 \\
(0.02-1.98)\end{array}$ & $\begin{array}{c}1.79 \\
(0.05-3.54) \\
\end{array}$ & $\begin{array}{c}0.86 \\
(0.00-1.76)\end{array}$ & $\begin{array}{c}0.00 \\
(0.00-0.00)\end{array}$ & 0.226 \\
\hline Scomber japonicus & $\begin{array}{c}223.41 \mathrm{ab} \\
(156.42-290.39)\end{array}$ & $\begin{array}{c}276.33 \mathrm{a} \\
(206.20-346.47)\end{array}$ & $\begin{array}{c}154.07 \mathrm{bc} \\
(92.72-215.42)\end{array}$ & $\begin{array}{c}99.15_{c} \\
(58.11-140.18)\end{array}$ & 0.001 \\
\hline
\end{tabular}


Table 4. Cont.

\begin{tabular}{|c|c|c|c|c|c|}
\hline \multirow[b]{2}{*}{ Fish Species } & \multicolumn{4}{|c|}{ Season of Capture } & \multirow[b]{2}{*}{$p$ Value } \\
\hline & $\begin{array}{l}\text { Spring } \\
(n=268)\end{array}$ & $\begin{array}{l}\text { Summer } \\
(n=278)\end{array}$ & $\begin{array}{l}\text { Autumn } \\
(n=267)\end{array}$ & $\begin{array}{c}\text { Winter } \\
(n=262)\end{array}$ & \\
\hline Scomber scombrus & $\begin{array}{c}331.92 \mathrm{a} \\
(222.84-441.00)\end{array}$ & $\begin{array}{c}353.03 \mathrm{a} \\
(259.81-446.25)\end{array}$ & $\begin{array}{c}211.33 \mathrm{ab} \\
(129.81-292.85)\end{array}$ & $\begin{array}{c}57.52 \mathrm{~b} \\
(33.21-81.83)\end{array}$ & 0.001 \\
\hline Solea vulgaris & 0.00 & 0.00 & 0.00 & 0.00 & - \\
\hline Sparus aurata & $\begin{array}{c}1.41 \\
(0.00-3.43)\end{array}$ & $\begin{array}{c}1.07 \\
(0.00-2.69)\end{array}$ & $\begin{array}{c}0.86 \\
(0.00-2.62)\end{array}$ & $\begin{array}{c}0.00 \\
(0.00-0.00)\end{array}$ & 0.529 \\
\hline Trachurus trachurus & $\begin{array}{c}160.30 \\
(89.30-231.29)\end{array}$ & $\begin{array}{c}118.21 \\
(70.53-165.88)\end{array}$ & $\begin{array}{c}128.33 \\
(69.00-187.66)\end{array}$ & $\begin{array}{c}136.48 \\
(85.09-187.88)\end{array}$ & 0.888 \\
\hline Overall & $\begin{array}{c}82.44 \mathrm{a} \\
(63.02-101.86)\end{array}$ & $\begin{array}{c}89.46 \mathrm{a} \\
(69.46-109.00)\end{array}$ & $\begin{array}{c}52.00 \mathrm{ab} \\
(38.47-65.53)\end{array}$ & $\begin{array}{c}34.01_{\mathrm{b}} \\
(24.91-43.11)\end{array}$ & 0.002 \\
\hline
\end{tabular}

\section{Discussion}

The present research aimed at providing, for the first time, epidemiological data regarding the presence Anisakis L3 larvae in 10 different fish species in the region of Vlora (Albania) over a 5-year period. It is important to highlight that all data reported in this study can be applied in risk assessment in the 10 analyzed fish species. Anisakiasis is a gastrointestinal fishborne zoonosis that is annually increasing in numerous countries in the Mediterranean area. Spain in particular has the highest reported incidence in Europe and the second highest worldwide [28]. The quantitative risk assessment analysis performed by Bao et al. [29] found that the risk of anisakiasis due to the consumption of raw or marinated unfrozen anchovies in the Spanish population was approximately $7700-8320$ cases per year.

Anisakids are known to be resistant to inadequate freezing (freezing in domestic freezers), microwaving, improper heating, and salting [30-32]. Moreover, visual inspection of the fish can detect $50 \%$ of the parasites, whereas in most cases, this cannot detect worms embedded deep in the fish musculature [23].

The present study revealed the absence of Anisakis larvae out of a total of 100 in all analyzed samples of Solea vulgaris in the coastal area of the Karaburun Peninsula in Vlora Bay. Few results are available in the literature regarding the presence of Anisakis larvae in the common sole (Solea solea). Its absence was observed by Keser et al. [33] in fish from the Dardanelles at Canakkale (Turkey). However, the number of fish specimens of common sole was limited to only 20 of them. Another study conducted by Abdel et al. [34] showed the presence of a nematode parasite belonging to the family Anisakidae in the genus Hysterothylacium along the city of Alexandria, Egypt in the Mediterranean Sea. Our study then showed that the species with the lowest prevalence and mean abundance were observed in Dicentrarchus labrax (9.17\% and 1.19, respectively) and Sparus aurata (4.55\% and 0.84 , respectively). It is also interesting to note that in this case, both species came from fish farms. This result may be due to the feeding procedures employed in the fish farms, where the anisakid life cycle is disrupted, providing non-viable L3 larvae. Furthermore, the chances of infected secondary or paratenic hosts entering cages and being eaten by farmed fish are modest $[35,36]$. However, rare incidents of an Anisakis presence in farmed fish have been observed by Marty et al. [37], who reported the presence of Anisakis spp. among farmed Atlantic salmon (Salmo salar). Even though, from the reported data, the level of Anisakis confirmed a low risk in farmed fish in the Vlora region, official systematic monitoring is necessary to ensure public health. According to European Regulation No. 853/2004 and No. 2074/2005, the risk of infection in farmed fish cannot be excluded. Indeed, sea-farmed fish are part of the monitoring plan under the organization of official controls.

Regarding high-risk species, in our study, they were represented by chub mackerel (Scomber japonicus), horse mackerel (Trachurus trachurus), and Atlantic mackerel (Scomber 
scombrus), showing the highest prevalence and mean abundance. The highest prevalence of infection (i.e., 74.1\%) was observed in S. japonicus, representing the most "high-risk" species in this research. Our findings are in agreement with reports by several authors [3841], where chub mackerel (S. japonicus) is the species with the highest infection level and mean intensity in the Mediterranean Sea. Prevalences similar to our data were found by Abattouy et al. [42] in Scomber japonicus from northern Moroccan waters, with a higher prevalence in Atlantic (67.9\%) than in Mediterranean (57.0\%) waters, and by Costa et al. [43] in mackerel from the Atlantic waters off Madeira (69.5\%).

Horse mackerel (Trachurus trachurus) represent a pelagic fish that easily becomes infected with Anisakis, with its diet consisting mainly of crustacea, mollusca, squids and small teleosts [44]. Our results revealed a prevalence of $68.2 \%$ in the viscera and $59.1 \%$ in the flesh in T. trachurus, in accordance with the high percentages observed in Southern Europe [45-47].

Regarding Atlantic mackerel (Scomber scombrus), they represent one of the most important pelagic fish widely propagating in the Pacific, northeast Atlantic, and Mediterranean areas. In general, mackerel caught in the Atlantic fishing grounds exhibit markedly higher Anisakis infection levels than their Mediterranean congeners [48]. In research conducted by Madrid et al. [49], the total Anisakis type I prevalence was $58.4 \%$. However, the fresh mackerel specimens were from both the Atlantic and Mediterranean areas.

In the present study, the percentage of infection in Engraulis encrasicolus was 50.0\%, in accordance with the data reported by Cipriani et al. [50], where similar prevalences of $55.8 \%$ and $39.8 \%$ in anchovy caught in the southern area of the Adriatic Sea and off the Croatian coast but always in the central area of the Adriatic Sea, respectively, were observed. Moreover, in the Adriatic Sea, a wide prevalence range of Anisakis infection (9.8-56.5\%) was reported in Engraulis encrasicolus and Sardina pilchardus along the coast of the Marche region (Central Italy) [51], and this wide range of values was also confirmed by another study [52], where for the same Italian coasts (central area of the Adriatic Sea), the highest levels of infection with the parasite (prevalence $=70.8 \%$; mean abundance $=4.30$ ) were found in Engraulis encrasicolus.

According to reports from several authors [53,54], in the anchovy musculature postmortem, larval migration is highly influenced by the freshness of the sample, being accelerated with the time lapsed from the moment the fish is caught. Moreover, rapid practices and correct evisceration after capture are fundamental to prevent larvae migration into the muscle [55].

In our research, albeit in lower percentages (10.5\%), Anisakis larvae were also observed in S. aurata. Goffredo et al. [47] showed a slightly higher percentage than that found in this study. It showed a prevalence of $19.5 \%$ (22 out of 113 specimens of S. aurata) in a study conducted in the Apulia region (Italy) on the opposite side of the Vlora region (Albania). Nevertheless, all the studies converged to one point and clearly established the percentage of Anisakis in sardines within the range of $10-20 \%$.

In general, beyond the fish species, in our study, there was a higher presence of Anisakis larvae in the viscera compared with that in the flesh $(33.58 \pm 1.4 \%$ vs. $27.91 \pm 1.4 \%$, respectively), in line with the results of Debenedetti et al. [26]. In this regard, several authors [56,57] reported on the Anisakis migration into the flesh from the viscera in the mackerel Scomber scombrus. The same authors in another study [58] highlighted that about 90-98\% are situated in the belly cavity and the visceral organs at the time of catch, and only few are embedded in the surrounding tissue of the peritoneal cavity in North Atlantic marine fish species.

Another important factor is the season of capture, as our results showed that, in general, it influenced the susceptibility to Anisakis infection. Significantly higher prevalences were observed in the summer and spring, while the lowest were observed in winter $(p<$ $0.05)$. These results are in agreement with several authors [26,42], and these differences could be due to the change in the population of intermediate hosts infected by these nema- 
todes and the possibility of a relationship between the feeding intensity of fish with these intermediate hosts and Anisakis infection.

\section{Conclusions}

This study, for the first time, evidently testifies to the presence of Anisakis parasites in several fish species along the Vlora coastline (southern Albania). Further studies are necessary to determine the presence of Anisakis larvae in other fishing areas throughout the Albanian coastline. Special attention should be especially given to Scomber japonicus, Scomber scombrus, and Trachurus trachurus, which showed the highest prevalence in this study.

Since the consumption of raw or undercooked fish is increasing in Albania, it is necessary to increase the number of sampling locations for official systematic monitoring plans. Furthermore, the correct adoption of mandatory and good hygiene practices (e.g., preventive freezing) in public establishments, such as restaurants where raw fish is consumed, is essential in order to prevent the circulation of the parasite. Moreover, the Anisakis larvae monitoring performed in this study may contribute to support the new challenges for sustainable aquaculture. In conclusion, a parasitological survey for Anisakis spp. larvae present in fish caught in Albania is crucial to ensure food safety, since the parasite being present in fish is a threat to public health.

Author Contributions: Conceptualization, E.O., A.V. and E.A.; methodology, E.O., A.V., and E.A.; formal analysis, L.M. and M.C.; investigation, E.O., A.V. and E.A.; data curation, L.M. and M.C.; writing-original draft preparation, E.O., A.V., E.A., M.C. and L.M.; writing-review and editing, E.O., A.V., E.A., M.C. and L.M.; visualization, E.O., A.V., M.C. G.B., G.C., S.A., D.M., L.M., C.M.B. and E.A.; supervision, E.O., A.V., E.A., M.C. and L.M.; project administration, E.O., A.V. and E.A. All authors have read and agreed to the published version of the manuscript.

Funding: This research received no external funding.

Institutional Review Board Statement: Not applicable.

Informed Consent Statement: Not applicable.

Conflicts of Interest: The authors declare no conflict of interest.

\section{References}

1. Kumar Maurya, A.; Faizabad Uttar Pradesh, K.; Hari Om Verma, I.; Pandey, G.; Pal, J.; Shukla, B.; Om Verma, H. A review on role of fish in human nutrition with special emphasis to essential fatty acid. Int. J. Fish. Aquat. Stud. 2018, 6, 427-430.

2. FAO_Food and Agricolture Organizations. The State of World Fisheries and Aquaculture 2018-Meeting the Sustainable 340 Development Goals; FAO: Rome, Italy; Available online: http:/ / www.fao.org/3/i9540en/i9540en.pdf (accessed on 4 October 2021 )2018.

3. WHO-World Health Organization. Soil-Transmitted Helminths; World Health Organization: Geneva, Switzerland, 2012; Available online: http:/ / www.who.int/intestinal_worms/en/ (accessed on 4 October 2021).

4. Caldeira, A.J.R.; Pereira Alves, C.P.; Santos, M.J. Anisakis notification in fish: An assessment of the cases reported in the European Union rapid alert system for food and feed (RASFF) database. Food Control 2021, 124, 107913. [CrossRef]

5. Orphanet Report Series Prevalence and incidence of rare diseases. Orphanet Rep. Ser. Rare Dis. Collect. 2020, 1, 1-94.

6. Aibinu, I.E.; Smooker, P.M.; Lopata, A.L. Anisakis Nematodes in Fish and Shellfish- from infection to allergies. Int. J. Parasitol. Parasites Wildl. 2019, 9, 384-393. [CrossRef]

7. Mattiucci, S.; Fazii, P.; De Rosa, A.; Paoletti, M.; Megna, A.S.; Glielmo, A.; De Angelis, M.; Costa, A.; Meucci, C.; Calvaruso, V.; et al. Anisakiasis and gastroallergic reactions associated with Anisakis pegreffii infection, Italy. Emerg. Infect. Dis. 2013, 19, 496. [CrossRef]

8. Mattiucci, S.; Cipriani, P.; Levsen, A.; Paoletti, M.; Nascetti, G. Molecular epidemiology of anisakis and anisakiasis: An ecological and evolutionary road map. Adv. Parasitol. 2018, 99, 93-263. [CrossRef]

9. Mattiucci, S.; Cipriani, P.; Paoletti, M.; Levsen, A.; Nascetti, G. Reviewing biodiversity and epidemiological aspects of anisakid nematodes from the North-east Atlantic Ocean. J. Helminthol. 2017, 91, 422-439. [CrossRef]

10. Nieuwenhuizen, N.E.; Lopata, A.L. Anisakis-A food-borne parasite that triggers allergic host defences. Int. J. Parasitol. 2013, 43, 1047-1057. [CrossRef]

11. Buchmann, K.; Mehrdana, F. Effects of anisakid nematodes Anisakis simplex (s.l.), Pseudoterranova decipiens (s.l.) and Contracaecum osculatum (s.1.) on fish and consumer health. Food Waterborne Parasitol. 2016, 4, 13-22. [CrossRef] 
12. Kassai, T.; Cordero Del Campillo, M.; Euzeby, J.; Gaafar, S.; Hiepe, T.; Himonas, C.A. Standardized nomenclature of animal parasitic diseases (SNOAPAD). Vet. Parasitol. 1988, 29, 299-326. [CrossRef]

13. Bao, M.; Pierce, G.J.; Strachan, N.J.C.; Pascual, S.; González-Muñoz, M.; Levsen, A. Human health, legislative and socioeconomic issues caused by the fish-borne zoonotic parasite Anisakis: Challenges in risk assessment. Trends Food Sci. Technol. 2019, 86, 298-310. [CrossRef]

14. Audicana, M.T.; Kennedy, M.W. Anisakis simplex: From obscure infectious worm to inducer of immune hypersensitivity. Clin. Microbiol. Rev. 2008, 21, 360-379. [CrossRef]

15. Audicana, M.T.; Ansotegui, I.J.; De Corres, L.F.; Kennedy, M.W. Anisakis simplex: Dangerous—dead and alive? Trends Parasitol. 2002, 18, 20-25. [CrossRef]

16. Serrano-Moliner, M.; Morales-Suarez-Varela, M.; Valero, M.A. Epidemiology and management of foodborne nematodiasis in the European Union, systematic review 2000-2016. Pathogens Global Health 2018, 112, 249-258. [CrossRef] [PubMed]

17. Deardoff, T.L.; Overstreet, R.M. Review of Hysterothylacium and Iberingascaris (both previously Thynnascaris) (Nematoda: 372 Anisakidae) from the northern gulf of Mexico. Proc. Biol. Soc. Wash. 1980, 93, 1035-1079.

18. EFSA Panel on Biological Hazards (BIOHAZ). Scientific opinion on risk assessment of parasites in fishery products. EFSA J. 2010, 8, 1543. [CrossRef]

19. Kim, S.H.; Park, C.W.; Kim, S.K.; Won, S.; Park, W.K.; Kim, H.R.; Nam, K.W.; Lee, G.S. A case of anisakiasis invading the stomach and the colon at the same time after eating anchovies. Clin. Endosc. 2013, 46, 293-296. [CrossRef] [PubMed]

20. Hochberg, N.S.; Hamer, D.H.; Hughes, J.M.; Wilson, M.E. Anisakidosis: Perils of the Deep. Clin. Infect. Dis. 2010, 51, 806-812. [CrossRef]

21. Brokaj, M. The Impact of the Gastronomic Offer in Choosing Tourism Destination: The Case of Albania. Acad. J. Interdiscip. Stud. 2014, 3, 249-258. [CrossRef]

22. Moravec, F. Parasitic Nematodes of Freshwater Fishes of Europe; Academia: Prague, Czech Republic; Kluwer Academic Publishers: Dordrecht, The Netherlands, 1994; Volume 385, p. 473.

23. Llarena-Reino, M.; Piñeiro, C.; Antonio, J.; Outeriño, L.; Vello, C.; González, F.; Pascual, S. Optimization of the pepsin digestion method for anisakids inspection in the fishing industry. Vet. Parasitol. 2013, 191, 276-283. [CrossRef]

24. ISS-Istituto Superiore di Sanità. European Union Reference Laboratory for Parasites. 2013. Available online: https://ec.europa. eu/food/system/files/2016-10/oc_eurl_wp_2013_parasites_in_particular_trichinella_echinococcus_and_anisakis.pdf (accessed on 4 October 2021).

25. Bush, A.O.; Lafferty, K.D.; Lotz, J.M.; Shostak, A.W. Parasitology meets ecology on its own terms: Margolis et al. revisited. J. Parasitol. 1997, 83, 575-583. [CrossRef] [PubMed]

26. Debenedetti, Á.L.; Madrid, E.; Trelis, M.; Codes, F.J.; Gil-Gómez, F.; Sáez-Durán, S.; Fuentes, M.V. Prevalence and risk of anisakid larvae in fresh fish frequently consumed in Spain: An overview. Fishes 2019, 4, 13. [CrossRef]

27. Rozsa, L.; Reiczigel, J.; Majoros, G. Quantifying parasites in samples of hosts. J. Parasitol. 2000, 86, 228. [CrossRef]

28. Herrador, Z.; Daschner, Á.; Perteguer, M.J.; Benito, A. Epidemiological scenario of anisakidosis in Spain based on associated hospitalizations: The tip of the iceberg. Clin. Infect. Dis. 2019, 69, 69-76. [CrossRef] [PubMed]

29. Bao, M.; Pierce, G.J.; Pascual, S.; González-Munõz, M.; Mattiucci, S.; Mladineo, I.; Cipriani, P.; Bušelić, I.; Strachan, N.J.C. Assessing the risk of an emerging zoonosis of worldwide concern: Anisakiasis. Sci. Rep. 2017, 7, 1-17. [CrossRef]

30. Sánchez-Alonso, I.; Carballeda-Sangiao, N.; González-Muñoz, M.; Navas, A.; Arcos, S.C.; Mendizábal, A.; Tejada, M.; Careche, M. Pathogenic potential of Anisakis L3 after freezing in domestic freezers. Food Control 2018, 84, 61-69. [CrossRef]

31. Brutti, A.; Rovere, P.; Cavallero, S.; D’Amelio, S.; Danesi, P.; Arcangeli, G. Inactivation of Anisakis simplex larvae in raw fish using high hydrostatic pressure treatments. Food Control 2010, 21, 331-333. [CrossRef]

32. Tejada, M.; Olivares, F.; de las Heras, C.; Careche, M.; Solas, M.T.; García, M.L.; Fernandez, A.; Mendizábal, A.; Navas, A.; Rodríguez-Mahillo, A.I.; et al. Antigenicity of Anisakis simplex s.s. L3 in parasitized fish after heating conditions used in the canning processing. J. Sci. Food Agric. 2015, 95, 922-927. [CrossRef] [PubMed]

33. Keser, R.; Bray, R.A.; Oguz, M.C.; Çelen, S.; Erdoğan, S.; Doğuturk, S.; Aklanoğlu, G.; Marti, B. Helminth parasites of digestive tract of some teleost fish caught in the Dardanelles at Çanakkale, Turkey. Helminthologia 2007, 44, 217-221. [CrossRef]

34. Abdel-Ghaffar, F.; Abdel-Gaber, R.; Bashtar, A.R.; Morsy, K.; Mehlhorn, H.; Al Quraishy, S.; Saleh, R. Hysterothylacium 412 aduncum (Nematoda, Anisakidae) with a new host record from the common sole Solea solea (Soleidae) and its role as a 413 biological indicator of pollution. Parasitol. Res. 2015, 114, 513-522. [CrossRef]

35. Crotta, M.; Ferrari, N.; Guitian, J. Qualitative risk assessment of introduction of anisakid larvae in Atlantic salmon (Salmo salar) farms and commercialization of products infected with viable nematodes. Food Control 2016, 69, 275-284. [CrossRef]

36. Skov, J.; Kania, P.W.; Olsen, M.M.; Lauridsen, J.H.; Buchmann, K. Nematode infections of maricultured and wild fishes in Danish waters: A comparative study. Aquaculture 2009, 298, 24-28. [CrossRef]

37. Marty, G.D. Anisakid larva in the viscera of a farmed Atlantic salmon (Salmo salar). Aquaculture 2008, 279, 209-210. [CrossRef]

38. Chaligiannis, I.; Lalle, M.; Pozio, E.; Sotiraki, S. Anisakidae infection in fish of the Aegean Sea. Vet. Parasitol. 2012, 184, 362-366. [CrossRef] [PubMed]

39. Mladineo, I.; Poljak, V. Ecology and genetic structure of zoonotic Anisakis spp. from adriatic commercial fish species. Appl. Environ. Microbiol. 2014, 80, 1281-1290. [CrossRef] [PubMed] 
40. Pekmezci, G.Z.; Onuk, E.E.; Bolukbas, C.S.; Yardimci, B.; Gurler, A.T.; Acici, M.; Umur, S. Molecular identification of Anisakis species (Nematoda: Anisakidae) from marine fishes collected in Turkish waters. Vet. Parasitol. 2014, 201, 82-94. [CrossRef]

41. Piras, M.C.; Tedde, T.; Garippa, G.; Virgilio, S.; Sanna, D.; Farjallah, S.; Merella, P. Molecular and epidemiological data on Anisakis spp. (Nematoda: Anisakidae) in commercial fish caught off northern Sardinia (western Mediterranean Sea). Vet. Parasitol. 2014, 203, 237-240. [CrossRef]

42. Abattouy, N.; López, A.V.; Maldonado, J.L.; Benajiba, M.H.; Martín-Sánchez, J. Epidemiology and molecular identification of Anisakis pegreffii (Nematoda: Anisakidae) in the horse mackerel Trachurus trachurus from northern Morocco. J. Helminthol. 2014, 88, 257-263. [CrossRef]

43. Costa, G.; Pontes, T.; Mattiucci, S.; D’Amélio, S. The occurrence and infection dynamics of Anisakis larvae in the black-scabbard fish, Aphanopus carbo, chub mackerel, Scomber japonicus, and oceanic horse mackerel, Trachurus picturatus from Madeira, Portugal. J. Helminthol. 2003, 77, 163-166. [CrossRef]

44. Cabral, H.N.; Murta, A.G. The diet of blue whiting, hake, horse mackerel and mackerel off Portugal. J. Appl. Ichthyol. 2002, 18, 14-23. [CrossRef]

45. Manfredi, M.T.; Crosa, G.; Galli, P.; Ganduglia, S. Distribution of Anisakis simplex in fish caught in the Ligurian Sea. Parasitol. Res. 2000, 86, 551-553. [CrossRef]

46. Tantanasi, J.; Diakou, A.; Tamvakis, A.; Batjakas, I.E. Anisakis spp. burden in Trachurus trachurus. Helminthologia 2012, 49, 16-20. [CrossRef]

47. Goffredo, E.; Azzarito, L.; Di Taranto, P.; Mancini, M.E.; Normanno, G.; Didonna, A.; Faleo, S.; Occhiochiuso, G.; D'Attoli, L.; Pedarra, C.; et al. Prevalence of anisakid parasites in fish collected from Apulia region (Italy) and quantification of nematode larvae in flesh. Int. J. Food Microbiol. 2019, 292, 159-170. [CrossRef] [PubMed]

48. Levsen, A.; Cipriani, P.; Mattiucci, S.; Gay, M.; Hastie, L.C.; MacKenzie, K.; Pierce, G.J.; Svanevik, C.S.; Højgaard, D.P.; Nascetti, G.; et al. Anisakis species composition and infection characteristics in Atlantic mackerel, Scomber scombrus, from major European fishing grounds-Reflecting changing fish host distribution and migration pattern. Fish. Res. 2018, 202, 112-121. [CrossRef]

49. Madrid, E.; Gil, F.; García, M.; Debenedetti, Á.L.; Trelis, M.; Fuentes, M.V. Potential risk analysis of human anisakiasis through the consumption of mackerel, Scomber scombrus, sold at Spanish supermarkets. Food Control 2016, 66, 300-305. [CrossRef]

50. Cipriani, P.; Sbaraglia, G.L.; Palomba, M.; Giulietti, L.; Bellisario, B.; Bušelić, I.; Mladineo, I.; Cheleschi, R.; Nascetti, G.; Mattiucci, S. Anisakis pegreffii (Nematoda: Anisakidae) in European anchovy Engraulis encrasicolus from the Mediterranean Sea: Fishing ground as a predictor of parasite distribution. Fish. Res. 2018, 202, 59-68. [CrossRef]

51. Fiovaranti, M.L.; Caffara, M.; Florio, D.; Gustinelli, A.; Marcer, F.; Gradassi, M.; Gavaudan, S.; Paolini, A.; Alessi, A.; Bisceglia, D Anisakisasis in anchovies (Engraulis encrasicolus) and sardines (Sardina pilchardus) caught along the Adriatic Coast. Parassitologia 2006, 48, 285.

52. Cipriani, P.; Acerra, V.; Bellisario, B.; Sbaraglia, G.L.; Cheleschi, R.; Nascetti, G.; Mattiucci, S. Larval migration of the zoonotic parasite Anisakis pegreffii (Nematoda: Anisakidae) in European anchovy, Engraulis encrasicolus: Implications to seafood safety. Food Control 2016, 59, 148-157. [CrossRef]

53. Mladineo, I.; Šegvić, T.; Petrić, M. Do captive conditions favor shedding of parasites in the reared Atlantic bluefin tuna (Thunnus thynnus)? Parasitol. Int. 2011, 60, 25-33. [CrossRef] [PubMed]

54. Suzuki, J.; Murata, R.; Hosaka, M.; Araki, J. Risk factors for human Anisakis infection and association between the geographic origins of Scomber japonicus and anisakid nematodes. Int. J. Food Microbiol. 2010, 137, 88-93. [CrossRef]

55. Chen, H.-X.; Zhang, L.-P.; Gibson, D.I.; Lü, L.; Xu, Z.; Li, H.-T.; Ju, H.-D.; Li, L. Detection of ascaridoid nematode parasites in the important marine food-fish Conger myriaster (Brevoort) (Anguilliformes: Congridae) from the Zhoushan Fishery, China. Parasites Vectors 2018, 11, 1-12. [CrossRef]

56. Karl, H.; Baumann, F.; Ostermeyer, U.; Kuhn, T.; Klimpel, S. Anisakis simplex (s.s.) larvae in wild Alaska salmon: No indication of post-mortem migration from viscera into flesh. Dis. Aquat. Organ. 2011, 94, 201-209. [CrossRef] [PubMed]

57. Smith, J.W. The abundance of Anisakis simplex L3 in the body-cavity and flesh of marine teleosts. Int. J. Parasitol. 1984, 14, 491-495. [CrossRef]

58. Karl, H. Nematode larvae in fish on the German market 20 years of consumer related research. Arch. Lebensmittelhyg. 2008, 59, 107-116. 